\title{
Preparation and Investigation of Corrosion and Biocompatibility Properties for Functionally Graded Materials (NiTi)
}

\author{
Nabaa S Radhi, Mohammad H Hafiz and Alaa Abdulhasan Atiyah
}

University of Babylon, Hilla, Iraq

\begin{abstract}
Functionally graded material (FGM) is new generations of composite materials where the properties are changed linearly according to the change in composition. This work presents the design, fabrication and characterization of multi $\mathrm{NiTi}$ shape memory alloys incorporated into single functionally graded materials. This design assumed to improve the general properties of NiTi shape memory alloys, especially the transformation temperature range. These materials are designed to have gradual microstructural or compositional variations within the body in one piece or single material. The powder metallurgy approach has been used extensively in preparing of NiTi alloys as well as the two models of functionally graded materials. The effect of layers composition, sintering time and temperatures was studied on the; microstructure as well as the developmental phases. Corrosion rate and characteristics as well as the toxicity of sintered materials are investigated also. Corrosion test results show that the current of corrosion (I ${ }_{\text {corr }}$.) for SMA-FGM samples are less than that obtained at each layer (i.e., $19.02,15.32 \mu \mathrm{A} / \mathrm{cm}^{2}$ for SMA-FGM SMA-FGM ${ }_{2}$ ) respectively, and Nickel ions percentage in Ringer solution after corrosion test show SMA-FGM SMA-FGM $_{2}$ samples less than each layer.
\end{abstract}

Keywords: Functionally graded material; Shape memory alloys; NiTi; Corrosion rate; Toxicity

\section{Introduction}

The idea of Functionally Graded Materials (FGMs) was substantially advanced in the early 1980s in Japan, where this new material concept was proposed to increase adhesion and minimize the thermal stresses in metallic-ceramic composites developed for reusable rocket engines [1]. Meanwhile, FGMs concepts have triggered world-wide research activity and are applied to metals, ceramics and organic composites to generate improved components with superior physical properties [2].

Today, production of graded structures can be considered as the next step in composite materials development. Functionally graded materials are a relatively new class of engineered materials in which the composition and/or microstructure varies in one specific direction. They are made by a continuous change in composition and do not possess a specific interface. Therefore, it is generally assumed that such a structure should better resist thermal and mechanical cycling [2].

\section{Literature Survey}

Bogdanski et al. in 2002 investigated the biocompatibility of nickel-titanium alloys by single-culture experiments on functionally graded samples with a stepwise change in composition from pure nickel to pure titanium, including a $\mathrm{Ni}-\mathrm{Ti}$ shape memory alloy for a 50:50 mixture [3].

This approach permitted a considerable decrease of experimental resources by simultaneously studying a full variation of composition. The results indicate a good biocompatibility for nickel content up to about $50 \%$. The cells used in the biocompatibility studies comprised osteoblast like osteosarcoma cells (SAOS-2, MG-63), primary human osteoblasts (HOB), and murine fibroblasts (3T3).

Fu et al. in 2003 have prepared the second type of functionally graded films involves new materials and functions other than TiNi films. Recently there have been some reports on the deposition of a functionally graded TiN/TiNi layer to fulfill this purpose [4]. The presence of an adherent and hard TiN layer $(300 \mathrm{~nm})$ on a TiNi film $(3.5 \mathrm{~lm}$ ) forms a good passivation layer (to eliminate the potential $\mathrm{Ni}$ release), and improves the overall hardness, load bearing capacity and tribological properties without sacrificing the shape memory effect of the TiNi films. In order to improve biocompatibility and adhesion of TiNi films, a functionally graded $\mathrm{Ti} / \mathrm{TiNi} / \mathrm{Ti} / \mathrm{Si}$ graded layer could be used. A thin covering layer of Ti can improve biocompatibility (to prevent potential $\mathrm{Ni}$ allergic reactions), while the Ti interlayer can be used to improve film adhesion [5-7].

\section{Corrosion of NiTi SMA}

Every metal has its own intrinsic toxicity to cells, but the corrosion mostly determines the existing concentration. Thus, the corrosion resistance of the alloy and the toxicity of individual metals in the alloy are the main factors determining its biocompatibility [8].

There are many studies on corrosion behavior of NiTi alloys. One reason for this is the fact that almost half of the atomic percentage weight of this alloy is Ni. Which is considered as one of the three heavy toxic elements frequently used in biocompatible alloys. The other two elements are $\mathrm{Cr}$ and V. Therefore, the safety and biocompatibility should be examined thoroughly. Over the last decade because of their unique shape memory effect and superelasticity characteristics, $\mathrm{NiTi}$ alloys have been increasingly considered for use in external and internal biomedical devices, e.g., Orthodontic wires, endodontic files, blade type dental implants, bone fracture fixation plates and nails, etc. Therefore for applications in the human body, the corrosion resistance of NiTi alloys becomes extremely important, as the amount and toxicity of corrosion products control the alloy biocompatibility [9-11].

In the galvanic series of metals, NiTi based alloys as a family are

*Corresponding author: Nabaa S Radhi, University of Babylon, Hilla, Iraq, Tel: 7801006256; E-mail: dr.nabbaa@gmail.com

Received November 25, 2017; Accepted January 16, 2017; Published January 22, 2018

Citation: Radhi NS, Hafiz MH, Atiyah AA (2018) Preparation and Investigation of Corrosion and Biocompatibility Properties for Functionally Graded Materials (NiTi). Ind Eng Manage S3: 005. doi: 10.4172/2169-0316.S3-005

Copyright: @ 2018 Radhi NS, et al. This is an open-access article distributed unde the terms of the Creative Commons Attribution License, which permits unrestricted use, distribution, and reproduction in any medium, provided the original author and source are credited. 
slightly nobler than stainless steel, and therefore, show comparable corrosion behavior. This better resistance is provided by a naturally formed thin oxide coating known as a passive film. The film is very stable; as a result the NiTi alloys are resistant to many forms of corrosive attacks. However in some aggressive conditions, such as highly acidified chloride solutions, break down of this passive film can occur [12].

Any local loss of passivity causes the risk of localized corrosion (pitting corrosion) with which microscopically small surface domains are subject to a rapid destructive attack while most of the neighboring areas practically stay intact [13]. The corrosion tests of implant materials may be carried out both in highly corrosive media such as $3.5 \%(\mathrm{w} / \mathrm{w})$ to $0.9 \%(\mathrm{w} / \mathrm{w}) \mathrm{NaCl}, 0.1 \mathrm{M} \mathrm{HCl}$ or $0.1 \mathrm{M} \mathrm{H}_{2} \mathrm{SO}_{4}$ and in media simulating biological electrolytes such as Ringer, Hank, and tyrode solutions or artificial saliva at body temperature of $37^{\circ} \mathrm{C}$ as a specified in ASTM F 2129 [14].

Although the above mentioned electrolytes simulate body fluids by reproducing the concentration of various salts, the in vivo corrosion measurements have indicated lower corrosion rates than those predicated from these in vitro experiments. The actual in vivo environment is made up of salts and proteins [15].

The release of Ni from Nitinol (a group of nearly equiatomic NiTi alloys with shape memory effect and superelasticity) is a central issue in its biocompatibility. However, our understanding of patterns of $\mathrm{Ni}$ release from the material evolved slowly. Observation on Nitinol prepared under laboratory conditions showed that Ni release might be higher than that from stainless steel during the first days of exposure to biological solution but it drops to almost undetectable levels after 10-14 days [16].

\section{Biocompatibility of NiTi SMA}

Biocompatibility is the primary requirement for biomaterials. Biocompatibility of implant devices relies on several issues which ultimately affects the performance of implant device. Inappropriate design of the implant devices, unwanted device degradation/corrosion and/or development of adverse host tissue reaction can lead to device failure. These reactions are usually highly undesirable and have the potential to lead to reactions such as chronic inflammation and or hypersensitivity. Hypersensitivity is either immediate or delayed response due to the contact with metals, corrosion products or metallic salts and is fairly common, affecting more than $15 \%$ of the population [10].

The controversial issue related to biocompatibility of NiTi is related to the high content of $\mathrm{Ni}$. The high risk triggered by Ni sensitive reactions is a problem when equiatomic NiTi is implanted into human beings. NiTi is an intermetallic compound with a well-defined regular crystal lattice order that exhibits high atomic bonding forces with mixed covalent and metallic character meaning that it is not easy to remove atoms from the bulk structure. Therefore, the most critical point with regard to the biocompatibility of NiTi as an implant is the interface between NiTi and body fluids.

\section{Toxicity and Carcinogenicity of Nickel}

The chemical toxicity of metal inside the body is closely related to the concentration of released ions and wear particles, the toxicity of these elements and the toxicity of the formed compounds. Even a poisonous substance has no toxic effects in small concentration, while nutritious substances cause adverse responses when present in excessive amounts. It is difficult to know the exact concentrations of metallic compounds released from implanted material, because there are many factors affecting them, such as implantation time and the local conditions ( $\mathrm{pH}$, fretting, etc.) [15].

The high nickel content of NiTi (54\% by weight) may cause biocompatibility problems if deleterious amounts of nickel dissolve from it. The toxicity of nickel has been studied using in vitro and in vivo nickel salts, solid nickel or particulate from nickel [17]. Nickel is known to have toxic effects with cellular damage in cell cultures at high concentration.

\section{Experimental Part}

\section{Starting materials}

The elemental powders (i.e., $\mathrm{Ni}$ and $\mathrm{Ti}$ powder) used in this research to prepare several SMA-FGMs layers with an average particle size, purity and origin are shown in Table 1.

\section{Plan of work}

The plane of work can be explained as following:

- Preparation of FGM layers according to pre designed model profile indicated in Tables 2 and 3.

- Wet mixing of the powders for 7 hours.

- Filling of powders into the die cavity by stepwise controlled manner.

- Compacting of powders with pressure.

- Sintering of all prepared samples in vacuum furnace with Argon inert gas.

\begin{tabular}{|c|c|c|c|}
\hline Powder & Average particle size $(\boldsymbol{\mu m})$ & Purity\% & Origin \\
\hline Nickel & 33 & 99.8 & BDH Chemicals Ltd Poole England \\
\hline Titanium & 165 & 98.5 & Fluke Chemi AGCH-9470 Bucks \\
\hline
\end{tabular}

Table 1: Powders used in this study.

\begin{tabular}{|c|c|c|}
\hline Layers & Chemical composition & Thickness (mm) \\
\hline $1^{\text {st }}$ & $50 \%$ at $\mathrm{Ti}-50 \%$ at $\mathrm{Ni}(45 \%$ wt $\mathrm{Ti}-55 \%$ wt $\mathrm{Ni})$ & 0.5 \\
\hline $2^{\text {nd }}$ & $49.3 \%$ at $\mathrm{Ti}-50.7 \%$ at $\mathrm{Ni}(44.2 \%$ wt $\mathrm{Ti}-55.8 \%$ wt $\mathrm{Ni})$ & 1.78 \\
\hline $3^{\text {rd }}$ & $48.5 \%$ at $\mathrm{Ti}-51.5 \%$ at $\mathrm{Ni}(43.5 \%$ wt $\mathrm{Ti}-56.5 \%$ wt Ni) & 3.07 \\
\hline $4^{\text {th }}$ & $47.8 \%$ at $\mathrm{Ti}-52.2 \%$ at $\mathrm{Ni}(42.7 \%$ wt $\mathrm{Ti}-57.3 \%$ wt $\mathrm{Ni})$ & 4.35 \\
\hline $5^{\text {th }}$ & $48.5 \%$ at $\mathrm{Ti}-51.5 \%$ at $\mathrm{Ni}(43.5 \%$ wt $\mathrm{Ti}-56.5 \%$ wt $\mathrm{Ni})$ & 3.07 \\
\hline $6^{\text {th }}$ & $49.3 \%$ at $\mathrm{Ti}-50.7 \%$ at $\mathrm{Ni}(44.2 \%$ wt $\mathrm{Ti}-55.8 \%$ wt $\mathrm{Ni})$ & 1.78 \\
\hline $7^{\text {th }}$ & $50 \%$ at $\mathrm{Ti}-50 \%$ at $\mathrm{Ni}(45 \%$ wt $\mathrm{Ti}-55 \%$ wt $\mathrm{Ni})$ & 0.5 \\
\hline
\end{tabular}

Table 2: Model of SMA-FGM, profile. 
Citation: Radhi NS, Hafiz MH, Atiyah AA (2018) Preparation and Investigation of Corrosion and Biocompatibility Properties for Functionally Graded Materials (NiTi). Ind Eng Manage S3: 005. doi: 10.4172/2169-0316.S3-005

Page 3 of 7

\begin{tabular}{|c|c|c|}
\hline Layers & Chemical composition & Thickness (mm) \\
\hline $1^{\text {st }}$ & $47.8 \%$ at $\mathrm{Ti}-52.2 \%$ at $\mathrm{Ni}(42.7 \%$ wt $\mathrm{Ti}-57.3 \%$ wt $\mathrm{Ni})$ & 0.5 \\
\hline $2^{\text {nd }}$ & $48.5 \%$ at $\mathrm{Ti}-51.5 \%$ at $\mathrm{Ni}(43.5 \%$ wt $\mathrm{Ti}-56.5 \%$ wt $\mathrm{Ni})$ & 1.78 \\
\hline $3^{\text {rd }}$ & $49.3 \%$ at $\mathrm{Ti}-50.7 \%$ at $\mathrm{Ni}(44.2 \%$ wt $\mathrm{Ti}-55.8 \%$ wt $\mathrm{Ni})$ & 3.07 \\
\hline $4^{\text {th }}$ & $50 \%$ at $\mathrm{Ti}-50 \%$ at $\mathrm{Ni}(45 \%$ wt $\mathrm{Ti}-55 \%$ wt $\mathrm{Ni})$ & 4.35 \\
\hline $5^{\text {th }}$ & $49.3 \%$ at $\mathrm{Ti}-50.7 \%$ at $\mathrm{Ni}(44.2 \%$ wt $\mathrm{Ti}-55.8 \%$ wt $\mathrm{Ni})$ & 3.07 \\
\hline $6^{\text {th }}$ & $48.5 \%$ at $\mathrm{Ti}-51.5 \%$ at $\mathrm{Ni}(43.5 \%$ wt $\mathrm{Ti}-56.5 \%$ wt $\mathrm{Ni})$ & 1.78 \\
\hline $7^{\text {th }}$ & $47.8 \%$ at $\mathrm{Ti}-52.2 \%$ at $\mathrm{Ni}(42.7 \%$ wt $\mathrm{Ti}-57.3 \%$ wt $\mathrm{Ni})$ & 0.5 \\
\hline
\end{tabular}

Table 3: Model of SMA-FGM2 profile.

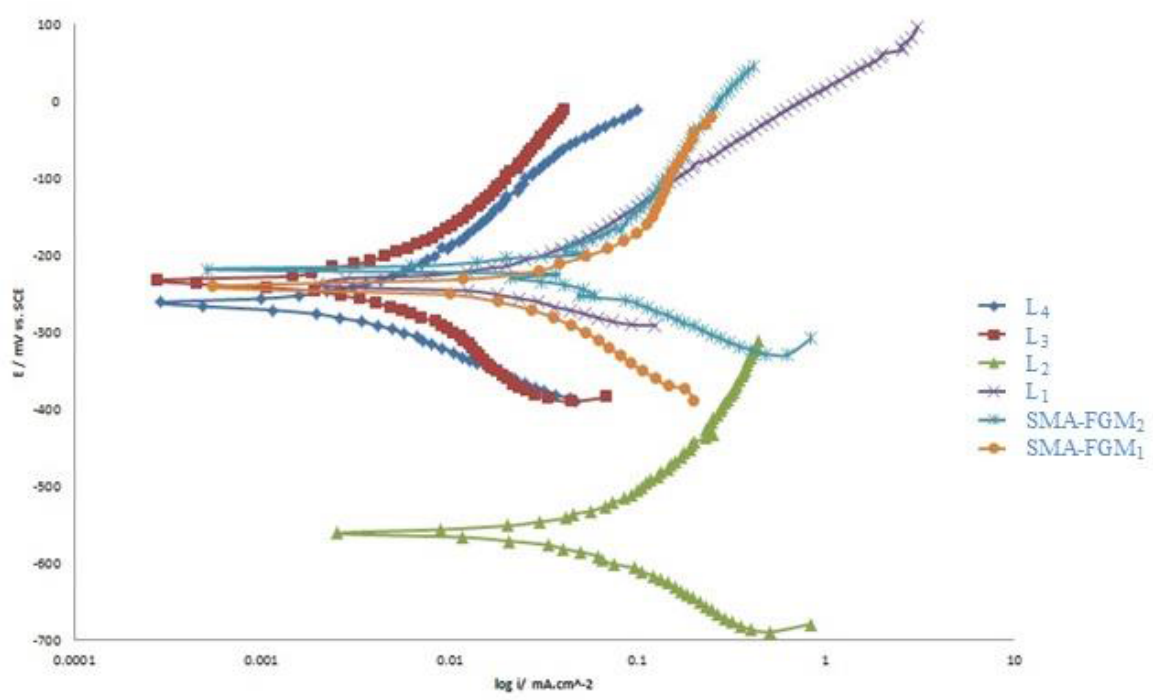

Figure 1: Corrosion potential measurements of materials immersed in artificial body fluid at $\mathrm{pH}=7.4$ and Temperature $37^{\circ} \mathrm{C}$.

- Using SEM for observation of microstructure using the SE technique to monitor topography, BSE technique to monitor different.

- Studying the corrosion and toxic behavior in Ringer solution.

\section{Corrosion Test}

For all tested samples the corrosion resistance of the samples was studied in synthetic Ringer's solutions which are mentioned below.

Samples for corrosion study were mounted in polyester to expose a surface area of $\left(1.76 \mathrm{~cm}^{2}\right.$ for each layer samples and for functionally graded samples $2.11 \mathrm{~cm}^{2}$ ). The electrolyte, cell assembly and the electrodes preparation for in vitro electrochemical studies are detailed below.

The basic experimental solution simulated human body fluid. It was prepared by adding Ringer tablet to 0.5 liter of distillated water and heated to temperature $120^{\circ} \mathrm{C}$ for $15 \mathrm{~min}$. The $\mathrm{pH}$ solution was 7.2 at $37^{\circ} \mathrm{C}$ temperature and then left to cool. Ringer tablets were obtained from Merck Company/Germany.

\section{Dissolution Test}

This test was achieved by using atomic absorption spectroscopy device in the State Company for Inspection and Engineering Rehabilitation (SIER), the electrolyte was taken after polarization test to toxic test to know the nickel percentage which dissolved in this electrolyte.

In order to determine the amount of $\mathrm{Ni}$ ions leached from the NiTi samples into Ringer's solution. The dissolution test was used to measure the ions in solution from the samples which has been immersed for 5 weeks at $37^{\circ} \mathrm{C}$ and the Ringer's solution after corrosion test, according to JOAN [18].

\section{Results and Discussion}

Corrosion Rate, toxicity and $\mathrm{Ni}$ ions release measurement:

The polarization tests were carried out using potentiostatic equipment on NiTi layer specimens with dimensions of $(15 \mathrm{~mm}$ in diameter and $2 \mathrm{~mm}$ in height) and SMA-FGM of dimensions of 15 $\mathrm{mm}$ in length and $14 \mathrm{~mm}$ in width, in synthetic body solution (Ringer solution) at $37 \pm 1^{\circ} \mathrm{C}$. The electrochemical behaviors of different types of NiTi were studied in the synthetic body solutions. The test specimens were polarized from cathodic to anodic regions at a sweep rate of 10 $\mathrm{mg} /$ minute. The potential Log current density plots were obtained for polarization of different specimens. These results are presented in Figure 1. The corrosion parameters obtained from this figure are $\mathrm{E}_{\text {corr }}$ and $\mathrm{i}_{\text {corr }}$.

The anodic polarization behavior of this layer was active due to an increase in current density, which leads to Ni dissolution after the corrosion potential has passed until reaching the last part of the polarization curve where the current density is reduced, indicating the critical current density and then it remains constant due to barrier film formation, which is similar to that observed by other investigators.

The lowest value of $\mathrm{E}_{\text {oc }}$ for $2^{\text {nd }}$ layer is in agreement with the results of polarization behavior as shown in Figure 1 and Table 4 they indicates that $2^{\text {nd }}$ layer have most negative value of corrosion potential 
Citation: Radhi NS, Hafiz MH, Atiyah AA (2018) Preparation and Investigation of Corrosion and Biocompatibility Properties for Functionally Graded Materials (NiTi). Ind Eng Manage S3: 005. doi: 10.4172/2169-0316.S3-005

Page 4 of 7

\begin{tabular}{|c|c|c|c|c|}
\hline Layers & Composition wt (\%) & $E_{\text {corr }}(\mathrm{mV})$ & $\mathrm{i}_{\text {corr }}\left(\mu \mathrm{A} / \mathrm{cm}^{2}\right)$ & Corr. Rate ${ }^{*} 10^{-5}(\mathrm{mpy})$ \\
\hline $\mathrm{L}_{1}$ & $(45 \mathrm{Ti}-55 \mathrm{Ni})$ & -238.0 & 12.74 & 2.0477 \\
\hline $\mathrm{L}_{2}$ & $(44.2 \mathrm{Ti}-55.8 \mathrm{Ni})$ & -561.5 & 46.30 & 7.4161 \\
\hline $\mathrm{L}_{3}$ & $(43.5 \mathrm{Ti}-56.5 \mathrm{Ni})$ & -231.3 & 2.19 & 0.3493 \\
\hline $\mathrm{L}_{4}$ & $(42.7 \mathrm{Ti}-57.3 \mathrm{Ni})$ & -263.5 & 1.98 & 0.3161 \\
\hline $\mathrm{SMA} \mathrm{FGM}_{1}$ & Multi layers & -243.1 & 19.02 & 2.5388 \\
\hline SMA-FGM 2 & Multi layers & -216.1 & 15.32 & 2.0420 \\
\hline
\end{tabular}

Table 4: Corrosion parameters for materials in human body conditions.

\begin{tabular}{|c|c|c|}
\hline Sample & Chemical composition & Amounts of Ni release (ppm) \\
\hline $1^{\text {st }}$ layer & $50 \%$ at $\mathrm{Ti}-50 \%$ at $\mathrm{Ni}(45 \%$ wt $\mathrm{Ti}-55 \%$ wt $\mathrm{Ni})$ & 0.27 \\
\hline $2^{\text {nd }}$ layer & $49.3 \%$ at $\mathrm{Ti}-50.7 \%$ at $\mathrm{Ni}(44.2 \%$ wt $\mathrm{Ti}-55.8 \%$ wt $\mathrm{Ni})$ & 0.010 \\
\hline $3^{\text {rd }}$ layer & $48.5 \%$ at $\mathrm{Ti}-51.5 \%$ at $\mathrm{Ni}(43.5 \%$ wt $\mathrm{Ti}-56.5 \%$ wt $\mathrm{Ni})$ & 0.25 \\
\hline $4^{\text {th }}$ layer & $47.8 \%$ at $\mathrm{Ti}-52.2 \%$ at $\mathrm{Ni}(42.7 \%$ wt $\mathrm{Ti}-57.3 \%$ wt $\mathrm{Ni})$ & 0.000 \\
\hline SMA-FGM & Multi layers & 0.013 \\
\hline SMA-FGM ${ }_{2}$ & Multi layers & 0.012 \\
\hline
\end{tabular}

Table 5: The concentration of $\mathrm{Ni}$ ions for each layer alloy and functionally graded samples after 5 weeks immersion in synthetic Ringer solution at $37^{\circ} \mathrm{C}$.

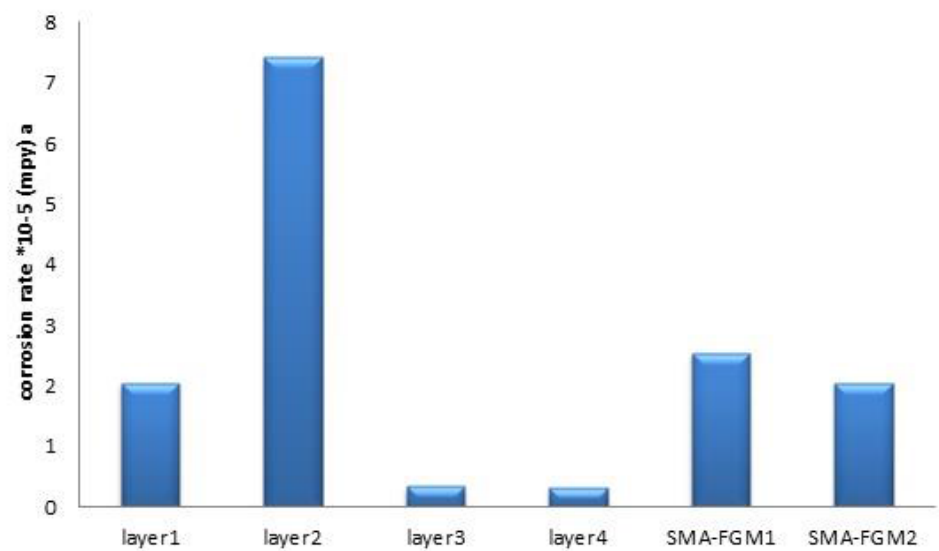

Figure 2: Corrosion rate measurements of materials immersed in artificial body fluid at $\mathrm{pH}=7.4$ and Temp. $37^{\circ} \mathrm{C}$.

and highest corrosion current density. It is known that any factor that enhances the value of $\left(\mathrm{i}_{\text {corr }}\right)$ results in an enhanced values of the corrosion rate on pure kinetic ground because of the rate of corrosion in a given environment. This is directly proportional to its corrosion current density. Figure 1 indicates that the polarization behavior of $\mathrm{L}_{2}$ in active region observed at more negative potentials and higher current densities.

While at anodic sites, the dissolution of metals in each material can occur and the lowest dissolution may be due to the stable phases or higher interaction among metals in materials produce. This stability in materials during manufacturing or preparation process of these materials. The order of corrosion potentials and corrosion current densities took the following sequences:

$$
\begin{array}{r}
\text { Nobility of } E_{\text {corr }} \text { SMA-FGM }>\mathrm{L}_{3}>\mathrm{L}_{1}>\mathrm{SMA}_{\mathrm{FGM}}>\mathrm{L}_{4}>\mathrm{L}_{2} \\
i_{\text {corr }} \mathrm{L}_{4}<\mathrm{L}_{3}<\mathrm{L}_{1}<\mathrm{SMA}-\mathrm{FGM}_{2}<\mathrm{SMA}-\mathrm{FGM}_{1}<\mathrm{L}_{2} .
\end{array}
$$

Corrosion rate measurements were done in Ringer solution at $37^{\circ} \mathrm{C}$ for all the samples (the each layer and those functionally graded samples). The results are represented graphically in Figure 1 that shows the corrosion rate of both (the layers and those functionally graded samples). Which have nearly the same corrosion rate, but it is a little bit higher for the layer which may be attributed to the higher Ni content compared to the other one.

It can also be attributed partly to the higher porosity percentage increases the actual surface area in contact with Ringer solution, hence, increasing the corrosion rate. These corrosion rate values for (the layers and those functionally graded samples) are shown in Figure 2.

Any metal intended for use as a biomaterial should exhibit excellent pitting and crevice corrosion resistance in body fluid. This can be determined by carrying out cyclic polarization experiments in body fluid at $37^{\circ} \mathrm{C}$. Generally, the reverse potentials more noble than forward potentials as shown in Table 4 . This indicates the possibility to produce passive film on the surfaces of experimental materials.

Figures 3-6 show SEM images for each layer and functionally graded samples after corrosion rate measurement and toxity test in Ringer solution at $\mathrm{pH}=7.4$ and Temp. $37^{\circ} \mathrm{C}$.

Nickel ions released in sufficient quantities from nickel-containing alloys may induce nickel sensitization or elicit allergic contact dermatitis [19]. Ni ions release test is used to insure the capability of NiTi shape memory alloys to be used in human bodies.

Figure 7 illustrates the concentration of $\mathrm{Ni}$ ions for each layer alloy and functionally graded samples after 5 weeks immersion in synthetic Ringer solution at $37^{\circ} \mathrm{C}$ as listed in Table 5. From the table, it is clear that the measurable amounts $(0.27)$ of $\mathrm{Ni}$ ions released from the first layer sample, while the measurable amounts for second, third, fourth layer, SMA-FGM and SMA-FGM ${ }_{2}$ sample are $(0.010,0.25,0.000,0.013$ and 0.012$) \mathrm{ppm}$ of Ni. These quantities are indicated the SMA-FGM 
Citation: Radhi NS, Hafiz MH, Atiyah AA (2018) Preparation and Investigation of Corrosion and Biocompatibility Properties for Functionally Graded Materials (NiTi). Ind Eng Manage S3: 005. doi: 10.4172/2169-0316.S3-005
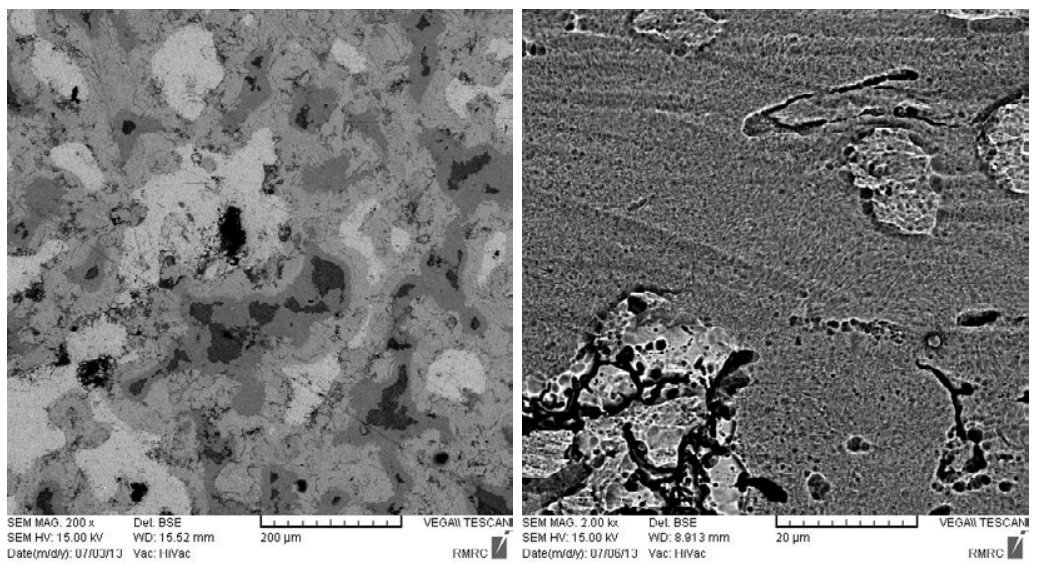

Figure 3: The SEM image for (a) first and (b) second layer after corrosion measurement in Ringer solution $\mathrm{pH}=7.4$ and Temp. $37^{\circ} \mathrm{C}$.
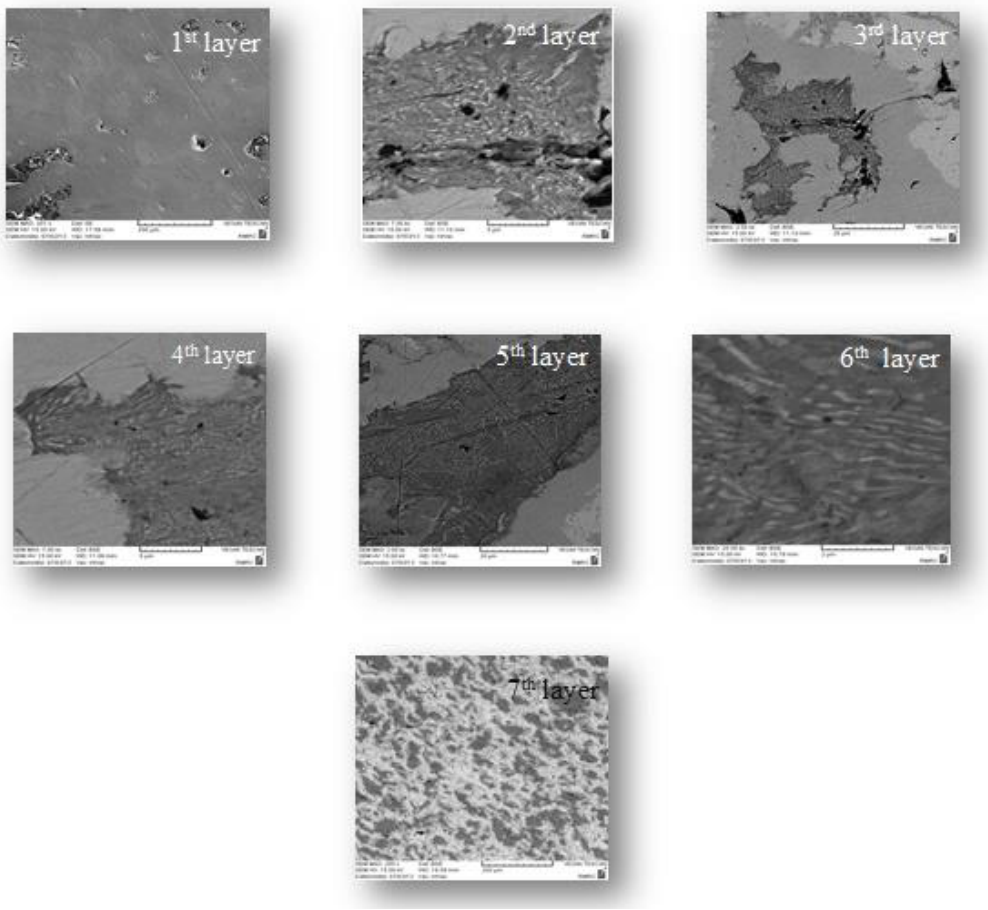

Figure 4: The SEM image for SMA-FGM1 samples after corrosion measurement in Ringer solution $\mathrm{pH}=7.4$ and Temp. $37^{\circ} \mathrm{C}$.

and SMA-FGM 2 samples much lower than each layer sample. These results indicate that SMA-FGM reduce $\mathrm{Ni}$ ions release from $\mathrm{NiTi}$ alloy.

The ability to induce cancer by medical implants is still questionable. Neither mutagenic effect in vitro nor carcinogenic effect after implantation in rates has been reported in Nitinol case [20].

Traditionally Ti was considered as a perfectly biocompatible metal because of its native "bioinert" surface oxide film [21]. Studies in vivo showed that $\mathrm{Ni}$ is efficiently eliminated from the body through urine and feces. Figure 7 show the toxicity of $\mathrm{Ni}$ in the Ringer solution after corrosion rate measurement.

\section{Conclusions}

Based on the results, the following conclusions may be described:
- Axisymmetric design of seven layered functionally graded materials was proposed to ensure a linear variation of constituents (i.e., $\mathrm{Ni}$ and $\mathrm{Ti}$ ) along the layers.

- The sintering at $\left(950^{\circ} \mathrm{C} \pm 5\right)$ for $(7 \mathrm{~h}$. $)$ of prepared samples seems to be real effective to satisfy sintering completely and transformed $\mathrm{Ni}$ and $\mathrm{Ti}$ into alloy structure which obtained.

- Scanning electron microscope observation indicated that all the samples compacted at (300) $\mathrm{MPa}$ and sintered at $950^{\circ} \mathrm{C} \pm 5$ for 7 hours have a clear martensitic structure.

- Corrosion test results show current of corrosion $\left(\mathrm{I}_{\text {corr. }}\right)$ for SMA-FGM samples less than each layer 19.02, $15.32 \mu \mathrm{A} /$ $\mathrm{cm}^{2}$ for SMA-FGM SMA-FGM ${ }_{2}$ respectively and Nickel ions percentage in Ringer solution after corrosion test show SMA- 

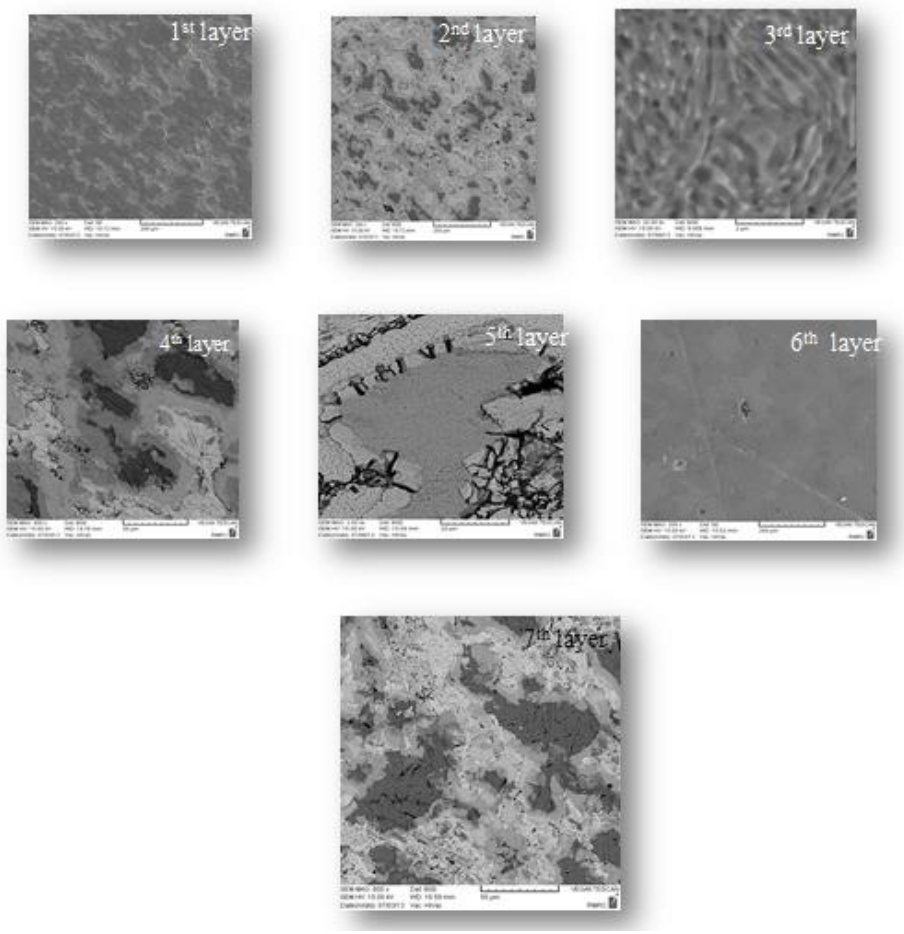

Figure 5: The SEM image for SMA-FGM2 samples after corrosion measurement in Ringer solution $\mathrm{pH}=7.4$ and Temp. $37^{\circ} \mathrm{C}$.
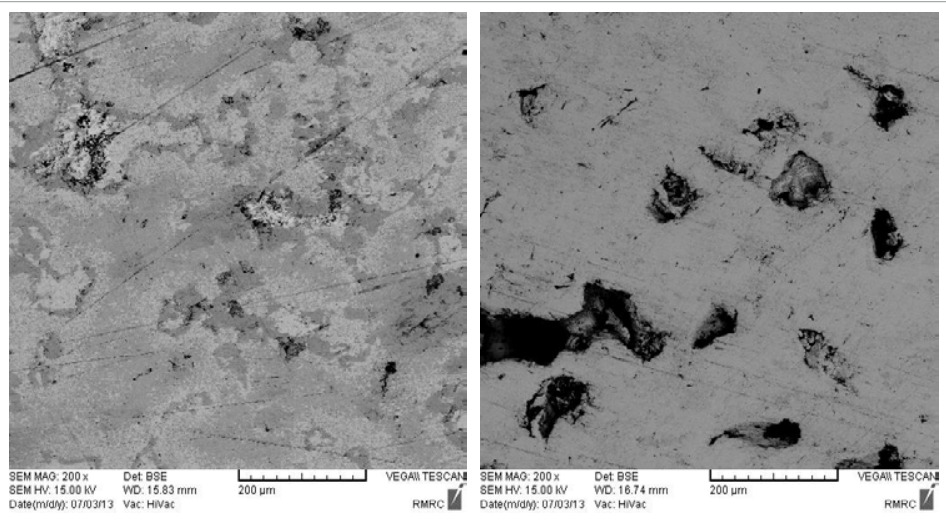

Figure 6: The SEM image for (c) third and (d) forth layer after corrosion measurement in Ringer solution $\mathrm{pH}=7.4$ and Temp. $37^{\circ} \mathrm{C}$.

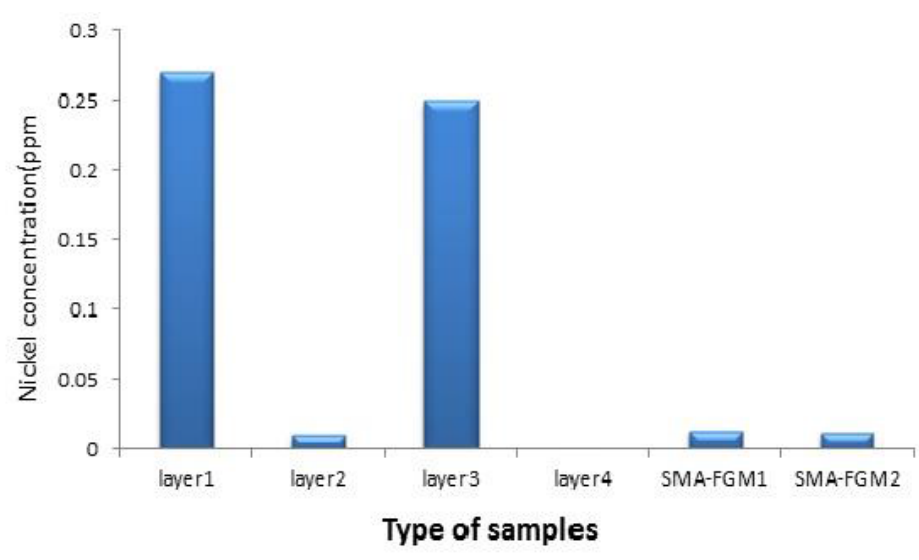

Figure 7: Show Nickel percentage of materials after corrosion rate measurement. 
Citation: Radhi NS, Hafiz MH, Atiyah AA (2018) Preparation and Investigation of Corrosion and Biocompatibility Properties for Functionally Graded Materials (NiTi). Ind Eng Manage S3: 005. doi: 10.4172/2169-0316.S3-005

$\mathrm{FGM}_{1}$ and SMA-FGM 2 samples less than each layer.

\section{References}

1. Koizumi M, Niino M (19950) Overview of FGM research in Japan. MRS Bull 20: $19-24$.

2. Mortensen A, Suresh S (1995) Functionally graded materials and metalceramic composites, Part I: Processing. Int Mater Rev 40: 239-265.

3. Bogdanski D, Koller M, Muller D, Muhr G, Bram M, et al. (2002) Easy assessment of the biocompatibility of $\mathrm{Ni}-\mathrm{Ti}$ alloys by in-vitro cell culture experiments on a functionally graded Ni-NiTi-Ti material. Biomaterials 23: 4549-4555.

4. Fu YQ, Du HJ, Zhang S (2003) Functionally graded TiN/TiNi shape memory alloy films, Mater Lett 57: 2995-2999.

5. Goldberg F, Knystautas EJ (1999) The effects of ion irradiation on TiNi shape memory alloy thin films. Thin Solid Films 342: 67-73.

6. Grummon DS, Gotthardt R (2000) Latent strain in titanium-nickel thin films modified by irradiation of the plastically-deformed martensite phase with $5 \mathrm{MeV}$ $\mathrm{Ni}_{2}$. Acta Mater 48: 635-646.

7. Lagrange TB, Gotthard R (2003) Microstructrual evolution and thermomechanical response of $\mathrm{Ni}$ ion irradiated TiNiSMA thin films. J Optoelectr Adv Mater 5: 313-318.

8. Shabalorskaya S (2002) Surface corrosion and biocompatibility aspects of Nitinol as an implant material. Bio-Medical Materials and Engineering 12: 69-109.

9. Dawood NM (2014) Preparation \& Characterization of Coated \& Cu alloyed Bio Nitinol. Ph.D. thesis, University of Technology, Department of Materials Engineering, Baghdad

10. Singh R, Pahotre NB (2007) Corrosion degradation and prevention by surface modification of bio metallic materials. J Mat Sci Mater 18: 725-751.
11. Trepanier C, Pelton A (2000) Biocompatibility and corrosion resistance of $\mathrm{NiTi}$. Cordis-NDC, Nitinol devices and components.

12. Cai Y, Liang C, Cui Z (2006) Formation of bone like appetite collagen composite coating on the surface of NiTi shape memory alloy. Script a Mater 54: 89-92.

13. Grummon DS, Zhang J, Pence TJ (1999) Relaxation and recovery of extrinsic stress in sputtered titanium-nickel thin films on (100)-Si. Mater Sci Eng A 275: 722-726.

14. Songer M, Celikkan H, Gokmese F (2004) Electrochemical corrosion properties of metal alloys used in orthopedic implants. J Apple Electrochemical 39: 12591265.

15. Yoneygma T, Miyazaki S (2009) Shape memory alloys for biomedical application. Cam Bridge, England.

16. Michiardi A, Aparicio C, Planell J (2006) New oxidation treatment of NiTi shape memory alloys to obtain Ni-free surfaces and to improve biocompatibility. J Biome Mater Res 77: 55-249.

17. Duerig TW, Tolomeo DE, Wholey M (2000) An overview of superelastic stent design. Min In vas ther Allied techno 9: 235-46 235.

18. Joan HY (2007) Plasma surface modification of biomedical polymers and metals. Ph.D. thesis, University of Sydney.

19. Richter V, Ruthendorf MV (2002) Final Report, DFG-Programme 322733 Project Gradient Formation in Hardmetals during Sintering

20. Costa M (1980) Principles and Methods of Industrial Metal Carcinogenesis Testing. Metal Carcinogenesis Testing, Human Press Inc., Clifton, NJ, pp: 149-164.

21. Williams D (1981) Biocompatibility of Clinical Implant Materials, CRC Press Boca Raton, FLA, pp: 9-44. 